\title{
Comparison of the Effectiveness of Piperacillin-Tazobactam and Carbapenems in Nosocomial Infections with Extended-Spectrum Beta- lactamase-Producing Escherichia coli and Klebsiella pneumoniae
}

\author{
Genişlemiş Spektrumlu Beta-laktamaz Üreten Escherichia colive Klebsiella pneumoniae \\ ile Gelişen Nozokomiyal Enfeksiyonlarda Piperasilin-Tazobaktam ve Karbapenemlerin \\ Etkinliğinin Karşılaştııılması
}

\author{
(D) Müge AYHAN ${ }^{1}$, (1) Bircan KAYAASLAN², (1) Imran HASANOĞLU², (1) Ayşe KAYA KALEM², (D) Dilek ASiLTÜRK², (1) Mehmet Akın \\ TAŞYARAN² , (1) Hatice Rahmet GÜNER²
}

\author{
${ }^{1}$ Ankara Atatürk Training and Research Hospital, Clinic of Infectious Diseases and Clinical Microbiology, Ankara, Turkey \\ ${ }^{2}$ Ankara Yıldırım Beyazıt University Faculty of Medicine, Department of Infectious Diseases and Clinical Microbiology, Ankara, Turkey
}

\section{Abstract}

Introduction: Infections with extended-spectrum beta-lactamase (ESBL)-producing strains are seen at increasing rates, resulting in increased morbidity, mortality, length of hospitalization, and cost. Effective and safe treatment of these infections is important. The aim of this study was to compare the effectiveness of piperacillin-tazobactam (PTZ) and carbapenems in nosocomial infections with ESBL-producing Escherichia coli and Klebsiella pneumoniae in hospitalized patients.

Materials and Methods: This study was performed retrospectively on patients who were infected with ESBL-producing E. coli and K. pneumoniae while hospitalized in Ankara Atatürk Tranining and Research Hospital between 2014 and 2017. Both PTZ- and carbapenem-susceptible isolates were included in the study. Patients with signs of infection who were older than 18 years, hospitalized for at least 48 hours, and received PTZ or carbapenem therapy were included in the study. Patients who received PTZ and carbapenem antibiotics consecutively in same infectious episode, received another antibiotic active against ESBL-producing microorganisms, received the selected antibiotic for less than 48 hours, or had polymicrobial infection were excluded from the study. Demographic characteristics, comorbid diseases, antibiotics used and their dose/duration, mechanical ventilation, presence of central catheter, clinical and microbiological responses to treatment, and end-of-treatment and 30-day mortality were recorded and compared. Results: Of the total 113 patients, 60 (53.1\%) were male and the mean age was $66.14 \pm 18.2$ years. Of the patients, $73.5 \%$ had $E$. coli and $26.5 \%$ had K. pneumoniae. Seventy patients (61.9\%) received carbapenem and 43 patients (38.1\%) received PTZ treatment. Microbiological eradication rate was $71.7 \%$ (43/60) in patients with control cultures. Clinical response was observed in $72.6 \%$ of the cases. The overall mortality rate was $31.0 \%$ ( $\mathrm{n}=35$ ). There were no significant differences between the groups in clinical and microbiological response ( $p=0.055 ; p=0.303)$ or end-of-treatment and 30 day mortality $(p=0.180, p=0.288)$. Age and bacteremia was found to be independent risk factors for mortality ( $p=0.006$ for both).

Conclusion: PTZ is an important alternative for infections caused by ESBL-producing microorganisms. In recent years, the need for rational antibiotic use has increased and carbapenem-sparing treatments have became more important. Piperacillin-tazobactam is one of the best alternatives and has comparable effectiveness in infections caused by ESBL-producing E. coli and Klebsiella spp.

Keywords: Extended-spectrum beta-lactamase, carbapenems, piperacillin-tazobactam, Escherichia coli, Klebsiella pneumoniae

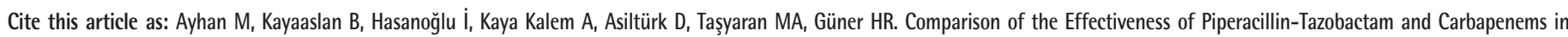
Nosocomial Infections with Extended-Spectrum Beta-lactamase-Producing Escherichia coli and Klebsiella pneumoniae. Mediterr J Infect Microb Antimicrob. $2020 ; 9: 3$. 
Giriş: Genişlemiş spektrumlu beta-laktamaz (GSBL) üreten suşlarla gelişen enfeksiyonlar artan oranlarla görülmekte, morbidite ve mortalitede, hastanede yatış süresinde ve maliyette artış ile sonuçlanmaktadır. Gelişen enfeksiyonların etkin ve güvenli tedavisi önemlidir. Bu çalışmada, yatan hastalarda GSBL üreten E. coli ve K. pneumoniae ile gelişen nozokomiyal enfeksiyonlarda piperasilin-tazobaktam (PTZ) ve karbapenemlerin etkinliğinin karşılaştırılması amaçlanmıştır.

Gereç ve Yöntem: Bu çalışmada Ankara Atatürk Eğitim ve Araştırma Hastanesi'nde 2014-2017 yılları arasında yatan, GSBL üreten E. coli ve K. pneumoniae ile enfekte hastaların sonuçları retrospektif olarak değerlendirildi. Çalışmaya hem PTZ hem karbapenemlere duyarlı olan üremeler dahil edildi. Enfeksiyon bulguları bulunan, 18 yaşından büyük, en az 48 saattir hastanede yatan, PTZ veya karbapenem tedavisi başlanan hastalar çalışmaya dahil edilirken aynı epizodda PTZ ve karbapenem grubu antibiyotikleri ardışık olarak alan, GSBL üreten mikroorganizmalara etkin başka bir antibiyotik kullanan, seçilen antibiyotiği 48 saatten az süre alan hastalar ve polimikrobiyal enfeksiyonu bulunan hastalar çalışma dışı bırakıldı. Hastaların demografik özellikleri, komorbid hastalıkları, aldığı antibiyotikler, doz ve süreleri, mekanik ventilasyon ve santral kateter varlığı, tedaviye klinik ve mikrobiyolojik yanıtları, tedavi sonu ve 30. gün mortalite verileri kaydedilerek karşılaştırmalı değerlendirildi.

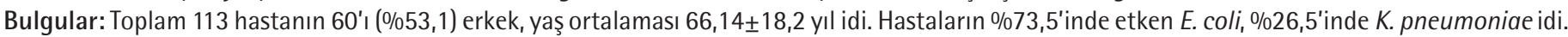
Hastaların 70'i $(\% 61,9)$ karbapenem, 43 'ü $(\% 38,1)$ PTZ tedavisi almıştı. Kontrol kültür alınan hastaların \%71,7'sinde $(43 / 60)$ mikrobiyolojik eradikasyon mevcuttu. Olguların \%72,6'sında klinik yanıt izlendi. Kaba mortalite hızı \%31,0 (35) idi. Klinik ve mikrobiyolojik yanıt ( $p=0,055$; $p=0,303$ ), tedavi sonu ve 30 günlük mortalite açısından $(p=0,180, p=0,288)$ gruplar arasında anlamlı fark saptanmadı. Yaş ve bakteriyemi varlığı mortalite için bağımsız risk faktörü olarak saptandı (her ikisi için $p=0,006$ ).

Sonuç: Sonuçta, PTZ, GSBL üreten mikroorganizmalar ile gelişen enfeksiyonların tedavisinde önemli tedavi seçeneklerindendir. Antimikrobiyal ajanların uygun kullanımına duyulan ihtiyacın arttığı, karbapenem koruyucu tedavilerin ön plana çıtığı günümüzde, PTZ en iyi alternatiflerden biridir ve GSBL üreten E. coli ve Klebsiella spp. enfeksiyonlarında kıyaslanabilir etkinliğe sahiptir.

Anahtar Kelimeler: Genişlemiş spektrumlu beta-laktamaz, karbapenem, piperasilin tazobaktam, Escherichia coli, Klebsiella pneumoniae

\section{Introduction}

Infections caused by extended-spectrum beta-lactamase (ESBL)-producing Enterobacteriaceae strains have become an increasingly important public health problem in recent years ${ }^{[1]}$. Higher morbidity and mortality result in prolonged hospitalization and increased $\operatorname{cost}^{[2]}$. It is critical to balance the effective and reliable treatment of infections caused by these agents with the principles of rational antibiotic use $\mathrm{e}^{[3]}$.

Escherichia coli and Klebsiella pneumoniae are the two most common ESBL-producing species, and are frequently seen in common infections such as urinary tract infections, pneumonia, and bacteremia ${ }^{[2,4,5]}$. Delays in appropriate antimicrobial treatment due to multidrug resistance in ESBL-producing microorganisms result in clinical failure and increased mortality ${ }^{[6,7]}$. Extended-spectrum beta-lactamase - type enzymes are in group $A$ according to the Ambler classification and are inhibited by beta-lactamase inhibitors such as clavulanic acid $^{[8]}$. This property is frequently exploited in phenotypic testing to detect ESBL-producing strains ${ }^{[0]}$. Extended-spectrum beta-lactamase enzymes can degrade penicillin, oxyiminocephalosporins, and monobactams. In addition, ESBL-producing Enterobacteriaceae can often be resistant to other classes of antibiotics such as fluoroquinolones, aminoglycosides, trimetoprim-sulfamethoxazole, and tetracyclines ${ }^{[1,10]}$. Therefore, reliable antibiotic options are limited ${ }^{[11,12]}$. Beta-lactam/betalactamase inhibitor combinations have been used in the treatment of infections caused by ESBL-producing strains and their treatment efficacy has been tested. Clinical failures have been reported, and they were attributed to the inoculum effect. However, the inoculum effect may be overcome in regions such as the urinary and biliary tracts, where piperacillintazobactam (PTZ) can reach high concentrations and be an effective treatment ${ }^{[13]}$. Carbapenems are not hydrolyzed by ESBL enzymes. Due to their safety profile and high efficacy, they are used as first-line agents in invasive infections caused by ESBLproducing strains, especially bloodstream infections ${ }^{[9]}$.

Various studies have shown that PTZ and carbapenems can have comparable efficacy in the treatment of ESBL infections. However, the applicability of these data is limited due to numerous factors, such as varying foci of infections caused by ESBL-producing microorganisms, differences in treatment dosage and duration, treatment with other antibiotics that are effective against ESBL-producing microorganisms, and differences in study endpoints ${ }^{[14]}$. Sharing real-world data on the effectiveness of treatments used for ESBL-producing Enterobacteriaceae strains will contribute to our knowledge with regards to an optimum therapeutic approach.

The aim of this study was to compare the clinical and microbiological effects of PTZ and carbapenem antibiotics in ESBL-producing E. coli and $K$. pneumoniae infections developed by inpatients in our hospital.

\section{Materials and Methods}

\section{Study Design}

In this study, we retrospectively compared the effectiveness of PTZ and carbapenem group antibiotics used as monotherapy 
in nosocomial infections caused by ESBL-producing E. coli and Klebsiella spp. among inpatients being treated in our hospital. Approval for the study was obtained from Ankara Yıldırım Beyazıt University Clinical Research Ethics Committee (approval date: 24.10.2018, no: 214). Due to the retrospective study design, informed consent form was not sought.

\section{Patient Selection}

Patients infected with ESBL-producing, PTZ- and carbapenemsensitive E. coli and K. pneumoniae strains in Ankara Yıldırım Beyazıt University Hospital between 2014 and 2017 were evaluated according to the inclusion criteria. Strains that were sensitive to both PTZ and carbapenems were included in the study. Patients with clinical signs of infection who were older than 18 years of age, hospitalized for at least 48 hours, and treated with PTZ or carbapenem (ertapenem, meropenem, imipenem) were included in the study. A single episode of infection was included in the analysis for each patient. Patients who used PTZ and carbapenem group antibiotics consecutively during the same episode of infection, used another antibiotic effective against ESBLproducing microorganisms (e.g., quinolones, aminoglycosides, cotrimoxazole, phosphomycin), used the selected antibiotic for less than 48 hours, or had polymicrobial infection were excluded from the study (Figure 1). If patients exhibited signs and symptoms of systemic infection together with signs specific to a focus of infection, treatment was initiated empirically and later adjusted according to agent and susceptibility when culture results became available. Microbiological identification was performed using conventional methods. Antibiotic susceptibility testing was performed using Vitek-2 (bioMerieux, France) and ESBL production in all E. coli and $K$. pneumoniae strains was confirmed using disc diffusion and evaluated according to Clinical and Laboratory Standards Institute standards ${ }^{[15]}$. Because strain-specific minimal inhibitory concentration (MIC) values were not in the patients' records, these could not be evaluated. Demographic and clinical data such as age and sex, history of surgery and comorbidities, antibiotics used, their dosage and duration, mechanical ventilation, central catheterization, and treatment response were recorded in patient information forms. Carbapenem and PTZ were compared in terms of clinical response, microbiological response, and end-of-treatment and 30-day mortality. In patients who did not need dose adjustment for any reason, treatment regimens were as follows: PTZ $4.5 \mathrm{~g}$ by 1 -hr infusion every 6 hours; meropenem $1 \mathrm{~g}$ by 3 -hr infusion every 8 hours; imipenem $500 \mathrm{mg}$ by 30-min infusion every 6 hours; ertapenem $1 \mathrm{~g}$ by 1 -hr infusion every 24 hours.

\section{Infection Definitions}

Primary bacteremia: Positive blood cultures that were laboratory-confirmed and not secondary to infection in another part of the body[16].
Pneumonia: Fever and other signs of systemic infection accompanied by presence of rales on physical examination, recent change in sputum volume or character, findings of progressive infiltration and consolidation on radiographic examination, and pathogen growth in cultures of significant sputum sample and deep tracheal aspirate.

Urinary tract infection: Fever and other signs of systemic infection accompanied by dysuria, urinary urgency, suprapubic tenderness, flank pain, and growth of $\geq 10^{5} \mathrm{CFU} / \mathrm{ml}$ in cleancatch urine culture.

Intraabdominal abscess: Fever and other signs of systemic infection accompanied by presence of intraabdominal abscess and positive culture of abscess drainage fluid ${ }^{[17-19]}$.

Deep tissue infection: Positive tissue culture with signs of systemic infection was considered deep tissue infection ${ }^{[20]}$, while pathogenic growth in culture of purulent synovial fluid (white blood cell count of 50,000-150,000/ $\mathrm{mm}^{3}$ ) with signs of systemic infection was considered septic arthritis ${ }^{[21]}$. Foci of infection were evaluated based on order of frequency. Foci other than primary bacteremia, pneumonia, and urinary tract infection were evaluated together in the "other" category due to small patient numbers in each group.

\section{A total of 162 nosocomial ESBL-producing E. coli and K. pneumoniae monomicrobial infection episodes in inpatients between 2014 and 2017 were evaluated.}

$\mathrm{n}=162$
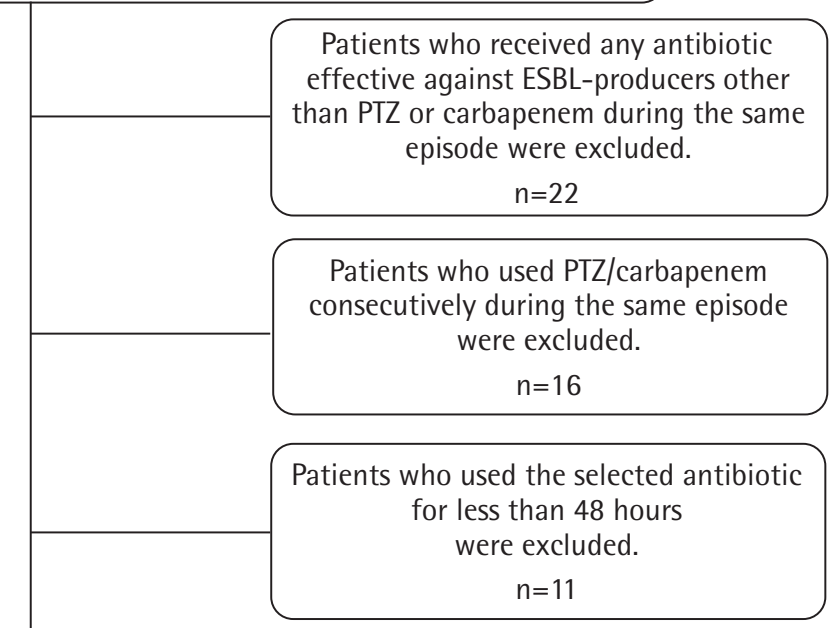

After applying the inclusion and exclusion criteria, a total of 113 patients were included in the study.

Figure 1. Flow chart of inclusion and exclusion of patients with extended-spectrum beta-lactamase-producing Escherichia coli and Klebsiella pneumoniae infections 


\section{Treatment Response}

Clinical response was defined as resolution of systemic symptoms (e.g., fever and hypotension) and site-specific symptoms within 48-72 hours after initiation of appropriate treatment. Microbiological response was defined as the absence of growth in control cultures obtained no earlier than 48-72 hours after the initiation of appropriate treatment. End-of-treatment mortality and 30-day mortality were recorded and compared between the groups.

\section{Statistical Analysis}

SPSS 18.0 software was used for the statistical analysis of the data. As descriptive statistics, number and percentage were calculated for categorical variables and mean, standard deviation, median, and minimum-maximum values were used for numerical variables. Chi-square test was used for comparison of categorical variables between two groups and Fisher's exact test was used when the assumptions for chi-square test were not met. Continuous variables were compared using Student's t-test, and Mann-Whitney $U$ test was used when parametric test conditions were unmet. Backward logistic regression analysis was used for multivariate analysis. A $p$ value $<0.05$ was considered statistically significant.

\section{Results}

Of the total 113 patients included in the study, 60 (53.1\%) were men and the mean age was $66.14 \pm 18.2$ years. History of surgery within the last 3 months was present in 58.4\% of the patients. The most common comorbidity was malignancy $(24.8 \%)$. Of the patients with malignancy, none had hematological malignancy. The causative pathogen was $E$. coli in $73.5 \%$ of the patients and $K$. pneumoniae in $26.5 \%$. The most common primary sites of infection were the urinary tract (37.2\%), bloodstream (15.9\%), and lung (15.9\%). Bacteremia was detected in $29.2 \%$ of the patients. Seventy patients $(61.9 \%)$ were treated with carbapenems, while $43(38.1 \%)$ received PTZ. Of 60 patients (53.1\%) who had control cultures, 43 (71.7\%) showed microbiological eradication. Clinical response was observed in $72.6 \%$ of the patients. The crude mortality rate was $31 \%$ (35). The patients' demographic characteristics and treatment responses are summarized in Table 1.

\begin{tabular}{|c|c|c|}
\hline Age, mean $\pm S D$ (min.-max.) & & $66.14 \pm 18.2(18-99)$ \\
\hline \multirow[t]{2}{*}{ Sex, \% (n) } & Male & $53.1 \%(60)$ \\
\hline & Female & $46.9 \%(53)$ \\
\hline \multirow{5}{*}{ Comorbidities, \% (n) } & Surgical history & $58.4 \%(66)$ \\
\hline & Malignancy & $24.8 \%(28)$ \\
\hline & Diabetes mellitus & $21.2 \%(24)$ \\
\hline & Chronic obstructive pulmonary disease & $8.8 \%(10)$ \\
\hline & Immunosuppression & $8.8 \%(10)$ \\
\hline \multirow[t]{2}{*}{ Invasive procedure, \% (n) } & Central venous catheter & $53.1 \%(60)$ \\
\hline & Mechanical ventilation & $38.1 \%(43)$ \\
\hline \multirow{2}{*}{ Isolated pathogen, \% (n) } & E. coli & $73.5 \%(83)$ \\
\hline & Klebsiella spp. & $26.5 \%(30)$ \\
\hline \multirow{4}{*}{ Primary infection site, $\%$ (n) } & Bloodstream & $15.9 \%(18)$ \\
\hline & Urinary tract & $37.2 \%(42)$ \\
\hline & Lung & $15.9 \%(18)$ \\
\hline & Other & $30.9 \%(35)$ \\
\hline Bacteremia, \% (n) & Present & $29.2 \%(33)$ \\
\hline Control culture, $\%$ (n) & Present & $53.1 \%(60)$ \\
\hline Microbiologic response $(n=60), \%(n)$ & Present & $71.7 \%(43)$ \\
\hline Clinical response, \% (n) & Present & $72.6 \%(82)$ \\
\hline \multirow{2}{*}{ End-of-treatment mortality, \% (n) } & Deceased & $31.0 \%(35)$ \\
\hline & Surviving (discharged or transplant) & $69.0 \%(78)$ \\
\hline 30-day mortality ( $n=91), \%(n)$ & & $40.6 \%(37)$ \\
\hline
\end{tabular}

SD: Standard deviation, min.: Minimum, max.: Maximum 
Other than median age and prevalence of central venous catheter, the groups were similar in terms of comorbidities, demographic characteristics, isolated pathogen, infection site, and prevalence of bacteremia. Univariate analysis revealed no significant differences in clinical and microbiological response, treatment duration, mortality, or 30-day mortality between the groups (Table 2). No difference was detected between the treatment groups in terms of mortality (Table 3 ).

\begin{tabular}{|c|c|c|c|}
\hline & PTZ $(n=43)$ & Carbapenem $(n=70)$ & $\mathrm{p}$ value \\
\hline Age, years (median, min.-max.) & $72(32-91)$ & $67(18-99)$ & $<0.05$ \\
\hline Sex, male, \% (n) & $46.5 \%(20)$ & $57.1 \%(40)$ & 0.183 \\
\hline Surgical history, \% (n) & $58.1 \%(25)$ & $58.6 \%(29)$ & 0.559 \\
\hline COPD, \% (n) & $11.6 \%(5)$ & $7.1 \%(5)$ & 0.312 \\
\hline Malignancy, $\%(n)$ & $27.9 \%(12)$ & $22.9 \%(16)$ & 0.350 \\
\hline Immunosuppression, \% (n) & $2.3 \%(1)$ & $12.9 \%(9)$ & 0.051 \\
\hline Diabetes mellitus, \% (n) & $20.9 \%(9)$ & $21.4 \%(15)$ & 0.573 \\
\hline Central catheter, $\%(\mathrm{n})$ & $67.4 \%(29)$ & $44.3 \%(31)$ & 0.013 \\
\hline Mechanical ventilation, $\%(\mathrm{n})$ & $41.9 \%(18)$ & $35.7 \%(25)$ & 0.324 \\
\hline Isolated pathogen, \% (n) & & & 0.315 \\
\hline E. coli & $69.8 \%(30)$ & $75.7 \%(53)$ & \\
\hline Klebsiella spp. & $30.2 \%(13)$ & $24.3 \%(17)$ & \\
\hline Infection site, $\%(n)$ & & & 0.452 \\
\hline Primary bacteremia & $13.9 \%(6)$ & $17.1 \%(12)$ & \\
\hline Pneumonia & $18.6 \%(8)$ & $14.3 \%(10)$ & \\
\hline Urinary tract infection & $44.2 \%(19)$ & $32.9 \%(23)$ & \\
\hline Other & $23.2 \%(10)$ & $35.7 \%(25)$ & \\
\hline Bacteremia (primary and secondary), \% (n) & $32.6 \%(14)$ & $27.1 \%(19)$ & 0.342 \\
\hline Clinical response, $\%(\mathrm{n})$ & $62.8 \%(27)$ & $78.6 \%(55)$ & 0.055 \\
\hline Control culture, \% (n) & $46.5 \%(20)$ & $57.1 \%(40)$ & 0.253 \\
\hline Microbiologic response, $\%(\mathrm{n})$ & $65.0 \%(13)$ & $75.0 \%(30)$ & 0.303 \\
\hline Mortality, \% (n) & $37.2 \%(16)$ & $27.1 \%(19)$ & 0.180 \\
\hline 30-day mortality ( $n=91), \%(n)$ & $\begin{array}{l}43.2 \%(16) \\
\text { Piperacillin-tazobactam } \\
(\mathrm{n}=37)\end{array}$ & $\begin{array}{l}38.8 \%(21) \\
\text { Carbapenem }(\mathrm{n}=54)\end{array}$ & 0.288 \\
\hline
\end{tabular}

COPD: Chronic obstructive pulmonary disease, PTZ: Piperacillin-tazobactam, min.: Minimum, max.: Maximum

\begin{tabular}{|c|c|c|c|}
\hline & Piperacillin-tazobactam & Carbapenem & p value \\
\hline \multicolumn{4}{|c|}{ Pneumonia $(n=18)$} \\
\hline Deceased $(n=9)$ & $6 / 8(75 \%)$ & $3 / 10(30 \%)$ & 0.077 \\
\hline Survived $(n=9)$ & $2 / 8(25 \%)$ & $7 / 10(70 \%)$ & \\
\hline \multicolumn{4}{|c|}{ Urinary tract infection $(n=42)$} \\
\hline Deceased $(n=13)$ & $6 / 19(31.6 \%)$ & $7 / 23(30.4 \%)$ & 0.599 \\
\hline Survived $(n=29)$ & $13 / 19(68.4 \%)$ & $16 / 23(69.6 \%)$ & \\
\hline \multicolumn{4}{|c|}{ Primary bacteremia $(n=18)$} \\
\hline Deceased $(n=10)$ & $3 / 6(50 \%)$ & 7/12 (58.3\%) & $>0.05$ \\
\hline Survived $(n=8)$ & $3 / 6(50 \%)$ & $5 / 12(41.6 \%)$ & \\
\hline \multicolumn{4}{|c|}{ Bacteremia (primary and secondary) $(n=33)$} \\
\hline Deceased $(n=17)$ & $5 / 14(35.7 \%)$ & $12 / 19(63.2 \%)$ & 0.114 \\
\hline Survived $(n=16)$ & $9 / 14(64.3 \%)$ & $7 / 19(36.8 \%)$ & \\
\hline
\end{tabular}




\section{Discussion}

ESBL-producing microorganisms are among the more difficult to treat pathogens due to the limited antibiotic options. The incidence of infection caused by ESBL-producing $E$. coli and $K$. pneumoniae strains has increased in recent years ${ }^{[22,23]}$. Carbapenems are frequently used in the treatment of infections caused by these microorganisms ${ }^{[24]}$. An increase in the frequency of carbapenem-resistant gram-negative bacteria has been observed over the last decade due to widespread carbapenem use ${ }^{[25]}$. Recent emphasis on the rational use of antimicrobial agents has necessitated the investigation of alternatives to carbapenems for the treatment of infections with ESBLproducing microorganisms ${ }^{[26]}$. Piperacillin-tazobactam, a broadspectrum drug active against gram-negative bacilli, is one of the antimicrobial agents most commonly used as an alternative to carbapenem and is a beta-lactam/beta-lactamase inhibitor effective against most ESBL-producing strains ${ }^{[27]}$. Different studies investigating the efficacy of PTZ and carbapenem in the empirical treatment of ESBL-producing gram-negative bacteremia have yielded conflicting results ${ }^{[14]}$.

In a study comparing empirical PTZ and carbapenem therapy in bacteremia caused by ESBL-producing $E$. coli and $K$. pneumoniae in a large series of 394 patients, no difference was observed between the two groups in terms of 30-day mortality or length of hospital stay, whereas the PTZ group showed much lower rates of multidrug-resistant microorganisms and fungal infections compared to the carbapenem group ${ }^{[6]}$. In another study performed in Turkey, no significant difference in 7-day and 30-day mortality rates was detected between the PTZ and carbapenem groups in a series 94 patients with ESBL-producing E. coli and K. pneumoniae bacteremia ${ }^{[28]}$. Unlike these studies, Tamma et al. ${ }^{[14]}$ reported that carbapenems were more effective in the treatment of infections caused by ESBLproducing microorganisms. They retrospectively compared the effectiveness of empirical PTZ and carbapenem therapy in 331 cases of bacteremia caused by ESBL-producing microorganisms and found that the use of empirical PTZ increased the mortality rate by 1.92 -fold. Therefore, they emphasized that carbapenem should be preferred in bacteremia caused by ESBL-producing pathogens in order to overcome the inoculum effect observed with gram-negative bacteria. Unlike these studies, we observed no significant difference between the PTZ and carbapenem groups in terms of mortality.

Most previous studies comparing these two groups of drugs involved bacteremic patients; those that include other infection sites are limited in number ${ }^{[3,9,29]}$. The present study included all infections caused by ESBL-producing microorganisms and evaluated the effectiveness of both groups of antibiotics in all nosocomial infections, including urinary tract infections, pneumonia, and bacteremia. Due to differences in the pharmacodynamic and pharmacokinetic characteristics of antibiotics, optimum antibiotic choices must be determined for the treatment of infections other than bacteremia. The review by Tamma and Rodriguez-Bano ${ }^{[4]}$ analyzed studies evaluating beta-lactam antibiotics other than carbapenem in ESBL-producing Enterobacteriaceae infections and showed that PTZ can be considered a noteworthy treatment option in mild/ moderate urinary and biliary tract infections, especially when the MIC with PTZ is $<4 \mu \mathrm{g} / \mathrm{ml}$. In the same study, it was stated that until more data are available, carbapenem antibiotics should be preferred for severely critical infections in which high inoculum effect may be observed and for infections with higher PTZ MIC value. Due to the lack of MIC values for the isolates in our study, the effect of MIC on treatment response could not be evaluated according to treatment option. In a meta-analysis of 35 studies, carbapenems were compared to other antibiotics active against ESBL-producing Enterobacteriaceae and it was reported that beta-lactam/beta-lactamase inhibitors were no less effective as definitive treatment than carbapenems if the microorganism is susceptible ${ }^{[30]}$.

The main limitations of our study are the small patient size, not performing power analysis during study design, the lack of patients' pre-treatment APACHE II scores, which precluded evaluation of disease severity in the patient group, and the insufficient number of deceased patients for an analysis of independent risk factors for mortality. The exclusion of patients who were treated with other antibiotics active against ESBLproducing microorganisms was the most important reason for the small patient sample. Another limitation is that a comparison among the carbapenems (imipenem, meropenem, ertapenem) could not be performed because small numbers of patients were treated with each one. Furthermore, the majority of the patient population had diseases that required surgery. The two main factors in this were the high proportion of patients being followed for malignant etiologies and the fact that our hospital performs a large number of trauma surgeries. Moreover another limitation of our study is that due to the small and heterogeneous patient groups for each infection focus and the absence of MIC values, the relationships between these factors and treatment response and mortality could not be evaluated.

\section{Conclusion}

PTZ is one of the most important alternatives to carbapenems for the treatment of ESBL-producing microorganism infections. A growing number of studies demonstrate that PTZ can be as effective as carbapenems. In our study, there was no difference between PTZ and carbapenem therapy in terms of treatment response or mortality, and PTZ was found to be as effective as carbapenems. With the growing need for rational 
use of antimicrobial agents and the increasing importance of carbapenem-sparing treatments, PTZ is currently one of the best alternative agents and has comparable effectiveness to carbapenems against ESBL-producing E. coli and Klebsiella spp. However, to determine the optimum treatment of ESBLproducing E. coli and Klebsiella bacteremia and nonbacteremic infections, much larger studies with more homogenously selected patient series are needed.

\section{Ethics}

Ethics Committee Approval: Approval for the study was obtained from Ankara Yıldırım Beyazıt University Clinical Research Ethics Committee (approval date: 24.10.2018, no: 214).

Informed Consent: Due to the retrospective study design, informed consent form was not sought.

Peer-review: Externally and internally peer-reviewed.

\section{Authorship Contributions}

Surgical and Medical Practices: M.A., B.K., A.K.K., I.H., Concept: M.A., B.K., H.R.G., Design: M.A., B.K., H.R.G., Data Collection or Processing: M.A., D.A., I.H., A.K.K., Analysis or Interpretation: M.A., B.K., M.A.T., Literature Search: M.A., B.K., Writing: M.A., B.K.

Conflict of Interest: No conflict of interest was declared by the authors.

Financial Disclosure: The authors declared that this study received no financial support.

\section{References}

1. Sfeir MM, Askin G, Christos P. Beta-lactam/beta-lactamase inhibitors versus carbapenem for bloodstream infections due to extended-spectrum betalactamase-producing Enterobacteriaceae: systematic review and metaanalysis. Int J Antimicrob Agents. 2018;52:554-70.

2. Tumbarello M, Spanu T, Di Bidino R, Marchetti M, Ruggeri M, Trecarichi EM, De Pascale G, Proli EM, Cauda R, Cicchetti A, Fadda G. Costs of Bloodstream Infections Caused by Escherichia coli and Influence of Extended-Spectrum-Lactamase Production and Inadequate Initial Antibiotic Therapy. Antimicrob Agents Chemother. 2010;54:4085-91.

3. Harris PN, Peleg AY, Iredell J, Ingram PR, Miyakis $S$, Stewardson AJ, Rogers BA, McBryde ES, Roberts JA, Lipman J, Athan E, Paul SK, Baker P, HarrisBrown T, Paterson DL. Meropenem versus piperacillin-tazobactam for definitive treatment of bloodstream infections due to ceftriaxone nonsusceptible Escherichia coli and Klebsiella spp. (the MERINO trial): study protocol for a randomised controlled trial. Trials. 2015;16:24.

4. Tamma PD, Rodriguez-Bano J. The Use of Noncarbapenem $\beta$-Lactams for the Treatment of Extended-Spectrum $\beta$-Lactamase Infections. Clin Infect Dis. 2017;64:972-80.

5. Ng TM, Khong WX, Harris PN, De PP, Chow A, Tambyah PA, Lye DC. Empiric Piperacillin-Tazobactam versus Carbapenems in the Treatment of Bacteraemia Due to Extended-Spectrum Beta-Lactamase-Producing Enterobacteriaceae. PLoS One. 2016;11:e0153696.

6. Tsai HY, Chen YH, Tang HJ, Huang CC, Liao CH, Chu FY, Chuang YC, Sheng WH, Ko WC, Hsueh PR. Carbapenems and piperacillin/tazobactam for the treatment of bacteremia caused by extended-spectrum $\beta$-lactamaseproducing Proteus mirabilis. Diagn Microbiol Infect Dis. 2014;80:222-6.

7. Tumbarello M, Sali M, Trecarichi EM, Leone F, Rossi M, Fiori B, De Pascale G, D'Inzeo T, Sanguinetti M, Fadda G, Cauda R, Spanu T. Bloodstream Infections Caused by Extended-Spectrum- -Lactamase- Producing Escherichia coli: Risk Factors for Inadequate Initial Antimicrobial Therapy. Antimicrob Agents Chemother. 2008;52:3244-52.

8. Wollheim C, Guerra IM, Conte VD, Hoffman SP, Schreiner FJ, Delamare AP, Barth AL, Echeverrigaray S, Costa SO. Nosocomial and community infections due to class $A$ extended-spectrum $\beta$-lactamase (ESBLA)-producing Escherichia coli and Klebsiella spp. in southern Brazil. Braz J Infect Dis. 2011;15:138-43.

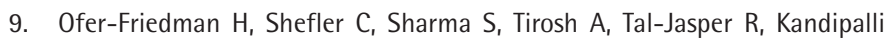
D, Sharma S, Bathina P, Kaplansky T, Maskit M, Azouri T, Lazarovitch T, Zaidenstein R, Kaye KS, Marchaim D. Carbapenems Versus PiperacillinTazobactam for Bloodstream Infections of Nonurinary Source Caused by Extended-Spectrum Beta-Lactamase-Producing Enterobacteriaceae. Infect Control Hosp Epidemiol. 2015;36:981-5.

10. López-Cerero L, Picón E, Morillo $C$, Hernández JR, Docobo F, Pachón J, Rodríguez-Baño J, Pascual A. Comparative assessment of inoculum effects on the antimicrobial activity of amoxycillin-clavulanate and piperacillintazobactam with extended-spectrum $\beta$-lactamase-producing and extended-spectrum $\beta$-lactamase-non-producing Escherichia coli isolates. Clin Microbiol Infect. 2010;16:132-6.

11. Sugimoto N, Yamagishi Y, Mikamo H. Proposed breakpoint of piperacillin/ tazobactam against extended spectrum $\beta$-lactamases producing bacteria in bacteremia. J Infect Chemother. 2017;23:65-7.

12. D'Angelo RG, Johnson JK, Bork JT, Heil EL. Treatment options for extendedspectrum beta-lactamase (ESBL) and AmpC-producing bacteria. Expert Opin Pharmacother. 2016;17:953-67.

13. Watkins $R R$, Deresinski S. Using $\beta$-lactam/ $\beta$-lactamase inhibitors for infections due to extended-spectrum $\beta$-lactamase-producing Enterobacteriaceae to slow the emergence of carbapenem-resistant Enterobacteriaceae. Expert Rev Anti Infect Ther. 2017;15:893-5.

14. Tamma PD, Han JH, Rock $C$, Harris AD, Lautenbach $E$, Hsu AJ, Avdic E, Cosgrove SE; Antibacterial Resistance Leadership Group. Carbapenem Therapy Is Associated With Improved Survival Compared With PiperacillinTazobactam for Patients With Extended-Spectrum -Lactamase Bacteremia. Clin Infect Dis. 2015;60:1319-25.

15. Clinical Laboratory Standards Institute (CLSI). Performance Standards for Antimicrobial Susceptibility Testing; M100, CLSI, (2013-2016). Available from: https://clsi.org/media/2663/m100ed29_sample.pdf

16. Centers for Disease Control and Prevention (CDC). Last Accessed Date: 8.05.2019. Available from: https://www.cdc.gov/nhsn/PDFs/ pscManual/4PSC_CLABScurrent.pdf

17. Garner JS, Jarvis WR, Emori TG, Horan TC, Hughes JM. CDC definitions for nosocomial infections. Am J Infect Control. 1988;16:128-40.

18. Centers for Disease Control and Prevention (CDC). Last Accessed Date: 08.05.2019. Available from: https://www.cdc.gov/nhsn/PDFs/ pscManual/2PSC_IdentifyingHAls_NHSNcurrent.pdf

19. Seifert H, Cornely O, Seggewiss K, Decker M, Stefanik D, Wisplinghoff $\mathrm{H}$. Bloodstream infection in neutropenic cancer patients related to short-termnontunnelled catheters determined by quantitative blood cultures, differential time to positivity, and molecular epidemiological typing with pulsed-field gel electrophoresis. J Clin Microbiol. 2003;41:118-23.

20. Stevens DL, Bisno AL, Chambers HF, Dellinger EP, Goldstein EJ, Gorbach SL, Hirschmann JV, Kaplan SL, Montoya JG, Wade JC. Practice Guidelines for the Diagnosis and Management of Skin and Soft Tissue Infections: 2014 Update by the Infectious Diseases Society of America. Clin Infect Dis. 2014;59:e1052. 
21. Margaretten ME, Kohlwes J, Moore D, Bent S. Does this adult patient have septic arthritis? JAMA. 2007;297:1478-88.

22. McDanel J, Schweizer $M$, Crabb V, Nelson $R$, Samore $M$, Khader $K$, Blevins $A E$, Diekema D, Chiang HY, Nair R, Perencevich E. Incidence of ExtendedSpectrum $\beta$-Lactamase (ESBL)-Producing Escherichia coli and Klebsiella Infections in the United States: A Systematic Literature Review. Infect Control Hosp Epidemiol. 2017;38:1209-15.

23. Pana ZD, Zaoutis T. Treatment of extended-spectrum $\beta$-lactamaseproducing Enterobacteriaceae (ESBLs) infections: what have we learned until now?. F1000Res. 2018;7. pii: F1000 Faculty Rev-1347.

24. Adler A, Katz DE, Marchaim D. The continuing plague of extended-spectrum B-lactamase-producing Enterobacteriaceae infections. Infect Dis Clin North Am 2016;30:347-75.

25. Perez LRR, Narvaez GA. Understanding the $\beta$-Lactam/Inhibitor of $\beta$-Lactamase Combinations: Reassessment for Better Antimicrobial Stewardship. Infect Control Hosp Epidemiol. 2017;38:881-3.

26. Hussein K, Sprecher H, Mashiach T, Oren I, Kassis I, Finkelstein R. Carbapenem Resistance Among Klebsiella pneumoniae Isolates Risk Factors, Molecular
Characteristics, and Susceptibility Patterns. Infect Control Hosp Epidemiol. 2009;30:666-71.

27. Schuetz AN, Reyes S, Tamma PD. Point-Counterpoint: PiperacillinTazobactam Should Be Used To Treat Infections with Extended-SpectrumBeta-Lactamase-Positive Organisms. J Clin Microbiol. 2018;56:e01917-7.

28. Sönmez U, Çalık Ş, Çayıröz MU, Olut Al, Arı A, Tosun S, Yiş R. Genişlemiş Spektrumlu Beta-Laktamaz Salgılayan Klebsiella pneumoniae ve Escherichia coli’ye Bağlı Bakteriyemilerde Mortalite ile İlişkili Risk Faktörlerinin Belirlenmesi ve Ampirik Piperasilin-Tazobaktam ile Karbapenem Tedavisi Sonuçlarının Karşılaştırılması. Ankem Derg. 2018;32:1-8.

29. Vardakas KZ, Tansarli GS, Rafailidis PI, Falagas ME. Carbapenems versus alternative antibiotics for the treatment of bacteraemia due to Enterobacteriaceae producing extended-spectrum $\beta$-lactamases: a systematic review and meta-analysis. J Antimicrob Chemother 2012;67:2793-803.

30. Son SK, Lee NR, Ko JH, Choi JK, Moon SY, Joo EJ, Peck KR, Park DA. Clinical effectiveness of carbapenems versus alternative antibiotics for treating ESBL-producing Enterobacteriaceae bacteraemia: a systematic review and meta-analysis. J Antimicrob Chemother. 2018;73:2631-42. 